University of Michigan Law School

University of Michigan Law School Scholarship Repository

\title{
Corporations, Shareholders' Right to Have a Dividend Declared and Paid Out of Surplus
}

Horace LaFayette Wilgus

University of Michigan Law School

Available at: https://repository.law.umich.edu/articles/882

Follow this and additional works at: https://repository.law.umich.edu/articles

Part of the Business Organizations Law Commons, Litigation Commons, and the Securities Law Commons

\section{Recommended Citation}

Wilgus, Horace LaFayette. "Corporations, Shareholders' Right to Have a Dividend Declared and Paid Out of Surplus." Mich. L. Rev. 17 (1919): 502-3.

This Response or Comment is brought to you for free and open access by the Faculty Scholarship at University of Michigan Law School Scholarship Repository. It has been accepted for inclusion in Articles by an authorized administrator of University of Michigan Law School Scholarship Repository. For more information, please contact mlaw.repository@umich.edu. 
Corporations, Shareholders' Right to Hafe a Dividend Dectared and PaId OUt of Surplus.-In Dodge v. Ford Motor Co. (Mich. s919), I70, N. W. 668 , the questions were not new, and with one exception, the decision was not unusual, but the sums involved were enormoús. The Motor Company was incorporated in I903, under the general manufacturing incorporating act of Michigan (P. A. 232, 1903), for the manufacture and sale of automobiles, motors and devices incident to their construction and operation, with an authorized Capital Stock of $\$ 150,000-\$ 100,000$ then paid up, $\$ 49,000$ in cash, $\$ 40,000$ in letters patent issued and applied for, and $\$ 11,000$ in machinery and contracts. In 1908 the stock was increased to $\$ 2,000,000$ by the declaration of a stock dividend of $\$ 1,900,000$. Plaintiffs own one-tenth of the stock.

By July 3r, I916, the Company had sold r,272,986 cars at a profit of \$173,895,416 ; it had paid regular dividends of $5 \%$ monthly, $60 \%$ or $\$ 1,200,000$ per annum on its capital stock of $\$ 2,000,000$, and in addition had paid special dividends of $\$ 1,000,000$ in $1911 ; \$ 4,000,000$ in $1912 ; \$ 10,000,000$ in 1913; $\$ 11$,000,000 in $1914 ;$ and $\$ 15,000,000$ in $1915-\$ 41,000,000$ in five years. It had also accumulated a surplus in excess of Capital Stock of $\$ 14,745,095$ in 1912; \$28,124,173 in 1913; $\$ 48,829,032$ in $1914 ; \$ 59,135,770$ in $1915 ;$ and $\$ 111,960,907$ in 1916. Its assets were $\$ 132,088,219$; and liabilities, other than Capital Stock and surplus, $\$ 18,127,312$.

The selling price of the car was originally fixed at $\$ 900.00$, but a policy of _annually reducing this had been carried out until the price of $\$ 440$ per car had been reached in 1914. This price was continued for the year 1915 in .order to accumulate a larger surplus with which greatly to enlarge the Company's plant, and various investments for this purpose were made during the year. Approximately 500,000 were sold this year at the $\$ 440$ price, and a net profit of nearly $\$ 60,000,000$ made. The directors then proposed. to reduce the price to $\$ 360$ per car, although there was a greater demand at the former price than the Company could supply, and it was practically certain 600,000 cars, and with a like profit, could be sold during the year at the forner price; in which case the new price would cut the net profits some $\$ 48,000,000$.

Plans were perfected in 1915-1916, and were about to be carried out for substantially doubling the manufacturing plant at an estimated cost of $\$ 9$,895,000 for buildings, $\$ 5,150,000$ for equipment, and $\$ 11,325,000$ for the construction of a smelter plant to make the iron used in the construction of the cars, the evidence showing that if this was done, the cost of the iron per car could be reduced about fifty per cent.

Plaintiffs brought suit to enjoin the carrying out of these projects, and to have a dividend of $50 \%$ of the accumulated profits declared and paid to shareholders. They contended:-(I) That the statute limiting the amount of Capital Stock with which a manufacturing company could be incorporated to $\$ 50,000,000$ made it unlawful for a corporation to accumulate from profits, and use in its business, more than $\$ 50,000,000$, and the balance over that must be distributed to shareholders. (2) That the building and operation of the smelter would be ultra vires. (3) That the reduction of the price of the car would make competition by others impossible, and thereby create a monopoly contrary to the anti-trust act; and, (4) That a failure to distribute a 
large part of the surplus as a dividend to shareholders, by the directors, was a breach of duty on their part.

The trial court held with the plaintiffs upon propositions ( 1 ), (2), and (4), and ordered the distribution of one-half of the surplus (after deducting the dividends already declared), as a special dividend to the shareholders, amounting to $\$ 19,275.385$. The Supreme Court reversed the lower court upon all these propositions except (4), and held there was no monopoly created contrary to the Anti-trust Law as alleged in proposition (3). In ruling as the Supreme Court did upon the first three propositions, it followed substantially all the authority there is.

In affirming the decree of the lower court. on proposition (4), the court relied mainly upon facts which showed clearly that more cars could be sold at the price of $\$ 440$ than the Company could make, and that Mr. Ford exercised a dominating influence over the business and had confessedly adopted an attitude toward the shareholders that, having already received great gains, they should be content with them or their continuance; that the profits were too large; and that by a reduction in the price, these profits should be shared with the public.

The court says, OsTrANDER, C. J., "A business corporation is organized primarily for the profit of the stockhoiders. The powers of the directors are to be employed for that end. The discretion of directors is to be exercised in the choice of means to attain that end, and does not extend to a change in the end itself, to the reduction of profits, or to the non-distribution of profits among shareholders in order to devote them to other purposes." "It is not within the lawful powers of a board of directors to shape and conduct the affairs of a corporation for the merely incidental benefit of shareholders, and for the primary purpose of benefiting others." All the judges concurred in the result.

H. L. W. 